Journal of Agricultural Sciences
(Tarim Bilimleri Dergisi)

\title{
In Situ and in Vitro Nutritive Value Assessment of Styrax Officinalis L. as an Alternative Forage Source for Goat Feeding
}

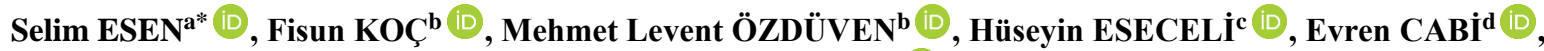 \\ Harun KARADAĞ $\breve{G}^{\mathrm{a}}$

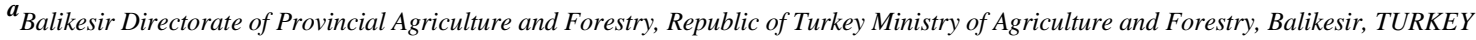

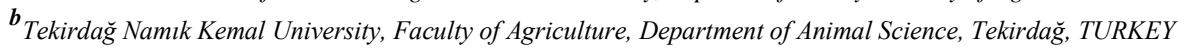

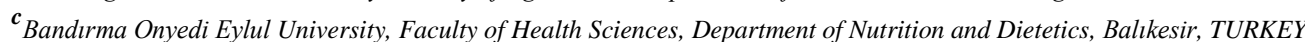

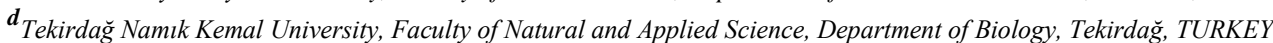

ARTICLE INFO

Research Article

Corresponding Author: Selim ESEN, E-mail: selim_esen01@ hotmail.com

Received: 31 January 2021 / Revised: 03 April 2021 / Accepted: 04 April 2021 / Online: 25 March 2022

ABSTRACT

The current study aimed to determine Styrax officinalis L. (SO) leaf's nutritive value, collected at four phenological stages, pre-flowering (PF), flowering (FL), seed linkage (SL), and fruiting (FR) by in situ and in vitro experiments. The ruminal degradability of dry matter (DM) and crude protein $(\mathrm{CP})$ and in vitro gas production (GP) of SO leaves were measured using three rumen fistulated mature Saanen goats. Significant differences between chemical compositions of the SO leaves collected at different phenological stages were observed $(\mathrm{P}<0.001)$. The DM, CP, ether extract (EE), and ash values of SO leaves ranged between 29.16 to $45.63 \%, 10.11$ to $19.79 \%, 3.40$ to $5.85 \%$, and 4.71 to $6.49 \%$ during the different phenological stages (PF, FL, SL and FR, respectively). Cell wall components of SO leaves showed a cubic trend due to their capability to form new shoots after grazing. The effective DM and CP degradability of SO leaves ranged between 66.91 to $77.93 \%$ and 64.92 to $84.57 \%$, which means an average value for animals fed at approximately maintenance level when rumen outflow rate (r) is equal to $0.02 \mathrm{~h}^{-1}$. Significant differences between the SO leaves collected at different phenological stages were observed in GP at all incubation times $(\mathrm{P}<0.05$ and $\mathrm{P}<0.001)$ After $96 \mathrm{~h}$ incubation, the gas produced ranged between 20.68 to 27.53 $\mathrm{mL} / 200 \mathrm{mg} \mathrm{DM}$ of the substrate. The research findings clearly indicate that degradability of DM, CP, and ME content of SO leaves ranged between moderate to high and significantly affected by phenological stages, however, they could be utilized until the end of the FL stage as forage sources.

Keywords: Styrax officinalis L. leaves, Ruminal degradability, Digestibility, Gas production, Chemical composition

(C) Ankara University, Faculty of Agriculture

\section{Introduction}

Goats, well-adapted species to marginal areas, can benefit from shrubs effectively, while other species cannot utilize them. In Turkey, goat breeding is characterized by low input usage and is carried out depending on natural conditions. Thus, natural pastures have an essential role in goat feeding. Therefore, shrublands in the Mediterranean climate zone represent valuable feed sources, especially in goats (Perevolotsky et al. 1998). In general, the quality of shrubland depends on the type, distribution, and nutrient composition of the plant. Indeed, shrublands become more important in meeting these animals' nutrient demands in dry seasons (Tölü 2009).

The nutrient composition of shrubs may vary according to seasons or even months (Rogosic et al. 2006). While new shoots and leaves rich in protein content accelerate in spring, protein content decreases, and cell wall components increase in summer. Acknowledgement of the changes in the shrubs' nutrient content throughout the year makes it an important source to decide the grazing season, determine additional feed strategies, establish the pasture-animal relationship correctly, and increase the economic and biological efficiency of breeding activities (Metera et al. 2010). In Turkey, shrublands are widely used for goat feeding throughout the year in some areas. Therefore, determining the animals' grazing preferences in shrublands is critical for these areas' sustainability. While there is a limited number of studies that were performed in Turkey aimed to determine the annual feed production of the shrubs, the change of feeding potential, and the grazing capacity, there are many studies on the nutritional composition of shrublands and consumption preferences of different species in these areas and about determining the feeding potential, in vitro gas production, and in sacco degradability characteristics of some of them in the literature (Dziba et al. 2003; Boubaker et al. 2004; Kamalak et al. 2004; Ammar et al. 2005; Moujahed et al. 2005; Karabulut et al. 2006; Rogosic et al. 2006; Salem et al. 2006; Bruno-Soares et al. 2011; González-Pech et al. 2021). 
Styrax officinalis L. (SO), which belongs to the Styracaceae family, is a deciduous plant in a dwarf tree or bush and is widely distributed in America, Mexico Mediterranean countries, e.g., Turkey, France, and Greece (Jaradat 2020). Although SO has deep roots, it has developed a root system that allows to benefit more from surface water due to their adaptation to drought (Mahall et al. 2010). The average 180-day life cycle starts with buds' blooming in early spring and ends with senescence in AugustSeptember. The main factor determining the growth and the number of leaves and flowers on the plant is the amount of rainfall in the previous year and varies according to annual rainfall (Mahall et al. 2010). The Phoenicians, Egyptians, and Romans used the resins of this plant for incense and treatment. It is widely found in the south, west, and northern parts of Turkey. Besides, the Styracacea family, e.g., S. japonicum, S. formosanus, S. obassia, S. macranthus, and S. officinalis, is known for its various biological activities in the form of insecticidal, fungicidal, antimicrobial, antidiabetic, antiproliferative, and cytotoxic effects (Łyczko et al. 2020; Yesilyurt \& Cesur 2020).

Briefly, it is possible to meet some of the nutrient requirements of goats from plant leaves and fruits that grow in shrublands in dry seasons. One of them is SO, which is widely distributed in the maquis vegetation. Therefore, the current study aimed to determine the nutritive value of SO leaf, collected at four phenological stages, by in situ and in vitro experiments.

\section{Material and Methods}

The present study was carried out from April to August 2019 in Balikesir, Turkey. The animal care and handling procedures were reviewed and approved by the Sheep Breeding Research Institute's Ethical Committee (Approval number: 3451976).

\subsection{Forage samples}

The leaf samples of SO was collected by hand-clipping from at least 20-30 different individual SO shrubs at pre-flowering (PF), flowering (FL), seed linkage (SL) and fruiting (FR) stages in four different district of Balikesir, Turkey (Bandirma (B), Erdek (E), Gönen (G), Manyas (M)) via three different sampling point. The amount of dry matter (DM) in the fresh form, collected from each sampling point, was determined on the same day by drying approximately $10 \mathrm{~g}$ of fresh material in an oven at $102^{\circ} \mathrm{C}$ for at least 16 hours until it reaches a constant weight. Fresh leaves were dried in air-conditioned rooms $\left(24 \pm 2{ }^{\circ} \mathrm{C}\right)$ by inverted several times a day for a week and were ground to pass through a $3 \mathrm{~mm}, 1 \mathrm{~mm}$, and $0.5 \mathrm{~mm}$ sieve kept in the refrigerator until analysis.

\subsection{Chemical analysis}

The proximate analysis of SO leaves used in the in situ and in vitro studies was performed according to Weende's analysis by using AOAC (1990) methods. Briefly, dry matter (DM) of SO was determined by drying the SO leaves at $102{ }^{\circ} \mathrm{C}$ overnight, and ash content was determined by ashing the SO leaves in a muffle furnace at $550{ }^{\circ} \mathrm{C}$ for $3 \mathrm{~h}$. The nitrogen (N) content of SO samples was measured by the Kjeldahl method and multiplied by 6.25 to get the crude protein (CP) ratio. To analyze the Neutral detergent fiber (NDF), acid detergent fiber (ADF), and acid detergent lignin (ADL) of SO, a method was used described by Van Soest et al. (1991). The condensed tannin (CT) content of SO samples were determined by Sun et al. (1998). While the samples milled through $1 \mathrm{~mm}$ were used for the proximate analysis with cell wall contents, milled through $0.5 \mathrm{~mm}$ was used to determine SO leaves' CT contents.

\subsection{In situ DM and CP degradation}

Three adult male Saanen goats, about 3 years old ages and $74.27 \pm 1.03 \mathrm{~kg}$ live weight (Mean $\pm \mathrm{SE}$ ), fitted with a permanent rumen cannula were used to measure the rate and extent of digestive DM and CP loss (digestibility, effective degradability) of SO leaves by using the in situ nylon bag technique (Ørskov \& McDonald 1979). Goats received a good quality alfalfa hay and concentrate (60:40) at about 1.25 times greater than maintenance level twice a day, at 09:00 and 16:30 at an equal amount. Nylon bags purchased from Ankom Technology (R510 forage bag, 5 x $10 \mathrm{~cm}$ size, $50 \pm 10 \mu$ porosity; ANKOM Technology, Macedon NY, USA). Approximately $3 \mathrm{~g}$ of SO leave, milled through $3 \mathrm{~mm}$, were placed in each nylon bag and incubated in the rumen of each of the three goats for specified periods $(3,6,12,24,48$, and $72 \mathrm{~h})$. Four bags, each containing one of the SO leaves collected from different phenological stages, were placed in each goat's rumen and then withdrawn at once after remaining in the rumen for the specified incubation time. Upon removal from the rumen, bags were immersed in a bucket of cold water, transferred into the laboratory, washed in running cold tap water for 2 minutes, and then washed in the cold rinse cycle (15 min) of a washing machine. Zero time disappearance was obtained by similarly washing un-incubated bags. The washed bags were dried in an airforced oven $\left(60 \pm 2{ }^{\circ} \mathrm{C}, 48 \mathrm{~h}\right)$ and weighed to determine DM disappearance. Digestion characteristics of DM and CP of SO leaves were calculated using equations 1 and 2 (Ørskov \& McDonald 1979):

$Y=a+b\left(1-e^{-c t}\right)$

$P=a+\frac{(b \times c)}{(c+r)}$ 
Where: $Y$, is the disappearance rate of DM or CP of SO leaves at time $\mathrm{t}(\%) ; a$, an intercept representing the portion of DM or CP of solubilized SO leaves at zero time incubation $(\%) ; b$, the portion of DM or CP of SO leaves that is readily degraded in the rumen $(\%) ; c$, the rate constant of fraction $b\left(\% \mathrm{~h}^{-1}\right) ; t$, is the time of incubation $(\mathrm{h}) ; P$, is the effective degradability of DM or CP of SO leaves (\%); $r$, is the rate of outflow from the rumen $\left(\% \mathrm{~h}^{-1}\right.$; an outflow rate of $0.02,0.05$, and 0.08 was applied).

\subsection{In vitro gas production}

In vitro incubations of SO leaves were carried out using the ANKOM RF Gas Production System (ANKOM Technology, Macedon NY, USA). Rumen fluid was obtained from three adult male Saanen goats before morning feeding. On each occasion, approximately $200 \mathrm{mg}$ SO leaves sample (dry weight), milled through $1 \mathrm{~mm}$, were incubated in triplicate in $250 \mathrm{~mL}$ glass bottles. The glass bottles were pre-warmed at $39{ }^{\circ} \mathrm{C}$ before the injection of $100 \mathrm{~mL}$ rumen fluid-buffer mixture (without trypticase; 20/80, v/v) by following the procedure of Goering \& Van Soest (1970). All the glass bottles containing rumen fluid-buffer mixture and SO leaves samples were incubated for specified times $(0,3,6,12,24,48,72$, and $96 \mathrm{~h})$. Total gas volume was corrected for blank incubation. Cumulative GP data were fitted to Ørskov \& McDonald (1979) model using the NEWAY computer package program according to equation 3 .

$Y=a+b\left(1-e^{-c t}\right)$

Where: $Y$, is the gas production volume $(\mathrm{GP})$ of $\mathrm{SO}$ leaves at time $\mathrm{t}(\mathrm{mL} / 200 \mathrm{mg} \mathrm{DM})$; $a$, gas production volume from immediately soluble fraction of SO leaves $(\mathrm{mL}) ; b$, gas production from the insoluble fraction of SO leaves (mL); $c$, gas production rate constant for the insoluble fraction of SO leaves $(\mathrm{mL} / \mathrm{h}) ; t$, the time of incubation.

The metabolizable energy (ME, MJ/kg DM) and organic matter digestibility (OMD, \% DM) contents of SO leaves were calculated using equations of Menke et al. (1979) (Equations 4 and 5).

$$
\begin{aligned}
& M E(M J / k g D M)=2.20+0.136 G P+0.057 C P \\
& O M D(\% D M)=14.88+0.889 G P+0.45 C P+0.0651 \text { Ash }
\end{aligned}
$$

Where: GP, is $24 \mathrm{~h}$ net gas production $(\mathrm{mL} / 200 \mathrm{mg})$; CP, crude protein.

\subsection{Statistical analysis}

In situ DM and CP degradation, data of chemical components, and in vitro GP and kinetics were analyzed applying a randomized complete block design using SAS (2016) pocket program. The least-squares means were compared using Tukey's multiple comparison tests. The model used for the least-squares (LS) analysis was as follows:

$Y_{i j k}=\mu+B_{i}+S_{j}+e_{i j k}$

Where: $Y_{i j k}$, is the variable studied; $B_{i}$, is the block; (B, E, G, M), $S_{j}$, is the phenological stages (PF, FL, SL, and FR); $e_{i j k}$, is the residual error. Linear, quadratic, and cubic trends of the phenological stage were analyzed according to orthogonal polynomial contrasts.

\section{Results and Discussion}

The chemical composition of the SO leaves collected at four different phenological stages is presented in Figure 1. Significant differences were observed between chemical compositions of the SO leaves collected at different phenological stages $(\mathrm{P}<0.001)$. DM contents of SO leaves ranged between 29.19 to $45.63 \%$ and increased with maturity, except the FL stage. In contrast to DM, SO leaves' CP content decreased with increased maturity and ranged between 10.11 to $19.79 \%$. CP content of SO leaves collected at the PF stage was significantly higher than those gathered at the other three stages (FL, SL, and FR). While the highest CP (19.79\%) and ash (6.49\%) contents were observed at the PF stage; the highest DM (45.63\%), EE (5.85\%), ADL $(10.14 \%)$, CT $(22.75 \%)$ contents were observed at FR stage as expected with increased maturity. CT content of SO leaves ranged between 6.42 to $22.75 \%$. Previous researchers have demonstrated that with the plant's increased maturity, the DM ratio increased while the CP ratio decreased (Mountousis et al. 2008; Tolunay et al. 2009; Ataşoğlu et al. 2010). The results obtained in the DM and $\mathrm{CP}$ ratio in the study are consistent with the literature reports on this subject. 

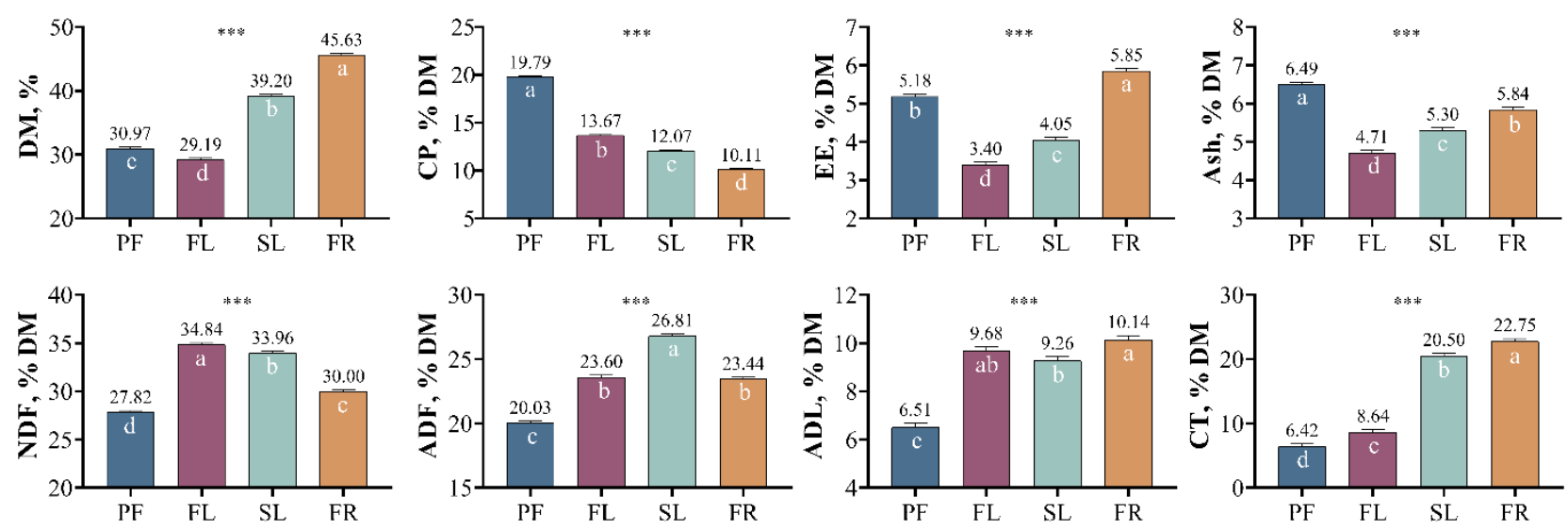

Figure 1- Chemical composition of Styrax officinalis L. leaves collected at different phenological stages

PF: Pre-flowering stage, FL: Flowering stage; SL: Seed linkage stage, FR: Fruiting stage; DM: Dry Matter; CP: Crude Protein; EE: Ether Extract; CA: Crude Ash; NDF: Neutral Detergent Fiber; ADF: Acid Detergent Fiber; ADL: Acid Detergent Lignin; CT: Condensed Tannin The values with different letters $(a, b, c, d)$ in each graph is statistically different $(\mathrm{P}<0.05)$; ***: $\mathrm{P}<0.001$.

In contrast, the increased level of DM of SO leaves with the SL stages in parallel to weather conditions, NDF, and ADF values were found to be decreased. These results may be accepted as an indicator that SO's leaf formation continues from new shoots after grazing. It was well documented in the literature that lignification was increased in plants as the maturity was increased (Parissi et al. 2005). In the present study, the ADL content of SO leaves was increased as the maturity was increased.

In a study conducted to determine the anti-methanogenic properties of some tree leaves containing tannins by in vitro gas production test, the DM, CP, EE, Ash, NDF, and ADF content of SO leaves was found to be $34.26 \%, 11.64 \%, 9.28 \%, 13.33 \%$, $28.95 \%$ and $22.94 \%$ respectively (Şimşek \& Kamalak 2019). In another study conducted to determine the yield and nutrient composition of shrubs in the pastures in Anti-Taurus Mountain, the CP, ADF, and NDF content of SO leaves was determined as $10.60 \%, 23.9 \%, 40.2 \%$, in Şavşak and $11.6 \%, 27.2 \%, 43.1 \%$ in Çandır, respectively (Kökten et al. 2010). However, it was not specified in which vegetation period or phenological stage the samples were taken in both studies. For this reason, it would not be easy to make an adequate comparison between the data obtained in our research and the literature reports. On the other hand, the results obtained in our study were found to be higher than the reported values of the SO leaves collected by Ertekin et al. (2019) at the FR stage.

The profiles for DM and CP disappearance of each phenological stage are illustrated in Figure 2, and degradability parameters are given in Tables 1 and 2. The mean rates of DM and CP disappearance were greater for the PF stage compared to the other three phenological stages (Figure 2). After a $48 \mathrm{~h}$ incubation period, DM disappearances between PF - FL and SL - FR were close to each other (Table 1). Except for the $12 \mathrm{~h}$ incubation period $(\mathrm{P}<0.01)$, all the incubation periods, degradability parameters, and effective degradability of SO leaves were significantly affected by the phenological stages $(\mathrm{P}<0.001)$. Also, significant differences between the phenological stages in terms of effective degradability of DM obtained from different rumen outflow rates were observed. While the SO leaves' highest effective degradability was observed at PF stages, the lowest effective degradability of SO leaves was marked at SL stages. Like the disappearances of DM of SO leaves, the CP degradability was significantly affected by the phenological stages $(\mathrm{P}<0.01$ and $\mathrm{P}<0.001)$ (Table 2$)$. There was a significant decrease in $\mathrm{CP}$ degradation in the rumen with increased maturity of SO. Approximately $27.94 \%$ decrease was observed between the beginning $(\mathrm{PF})$ and the end of the vegetation period (FR) for the readily degradable part of $\mathrm{CP}$ of SO leaves. 


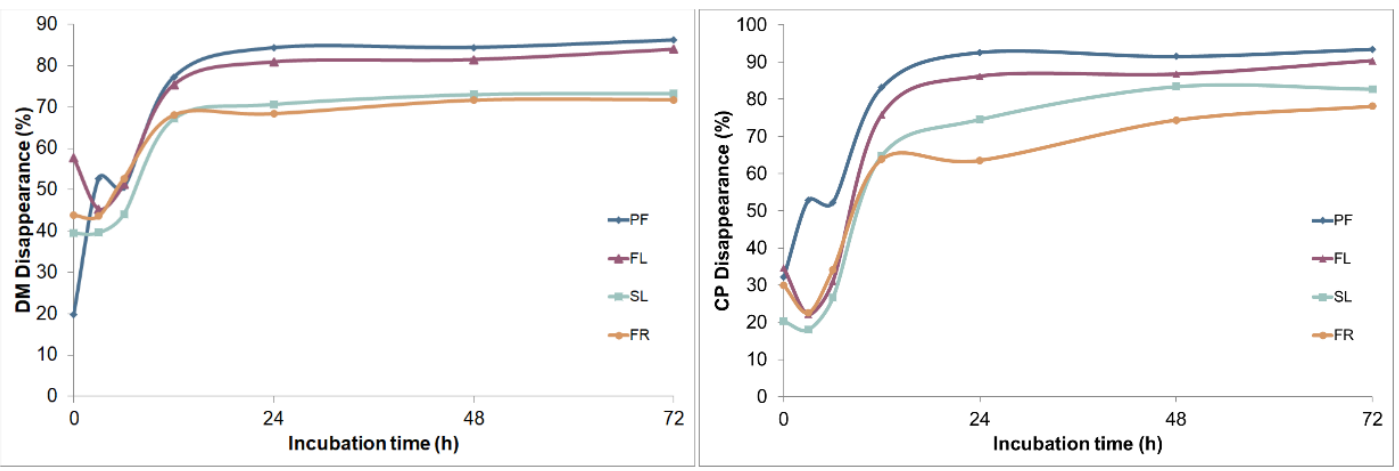

Figure 2- Degradation curve of dry matter and crude protein of Styrax officinalis L.

PF: Pre-flowering stage; FL: Flowering stage; SL: Seed linkage stage; FR: Fruiting stage; DM: Dry Matter; CP: Crude Protein

Table 1- Degradability coefficients and effective degradability of DM of Styrax officinalis L.

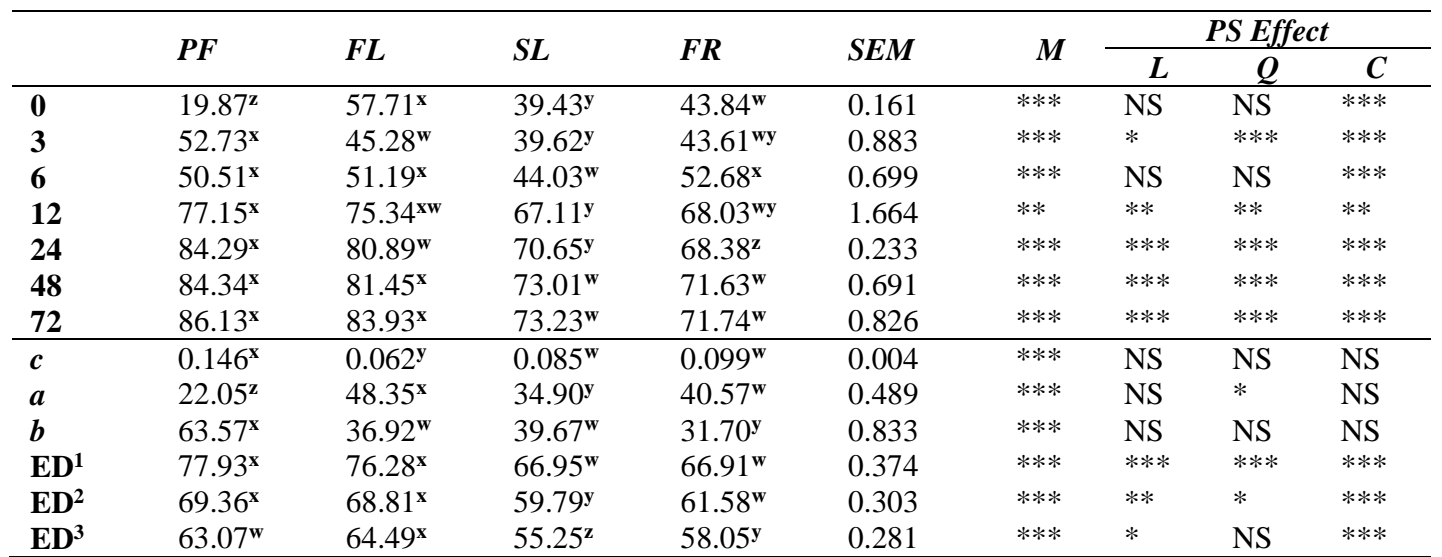

IT: Incubation time (h); PS: Phenological stages; PF: Pre-flowering stage; FL: Flowering stage; SL: Seed linkage stage; FR: Fruiting stage; SEM: Standard error of means; M: Main effect; L: Linear effect; Q: Quadratic effect; C: Cubic effect; a: the fraction of readily degradable DM (\%); b: the fraction of degradable DM at a measurable rate (\%); c: degradation rate of DM $\left(\% \mathrm{~h}^{-1}\right)$; $\mathrm{ED}^{1}$ : effective degradability of DM $(\%)$ with a rumen outflow rate of $0.02 ; \mathrm{ED}^{2}:$ effective degradability of $\mathrm{DM}(\%)$ with a rumen outflow rate of $0.05 ; \mathrm{ED}^{3}$ : effective degradability of $\mathrm{DM}(\%)$ with a rumen outflow rate of 0.08 ; The values with different letters (x, w, $\mathrm{y}, \mathrm{z}$ ) in the same row are statistically different $(\mathrm{P}<0.05)$, NS: Not Significant; *: $\mathrm{P}<0.05$, **: $\mathrm{P}<0.01, * * *$ : $\mathrm{P}<0.001$.

Table 2- Degradability coefficients and effective protein degradability of Styrax officinalis L.

\begin{tabular}{|c|c|c|c|c|c|c|c|c|c|}
\hline \multirow{2}{*}{$I T$} & \multirow{2}{*}{$P F$} & \multirow{2}{*}{$F L$} & \multirow{2}{*}{$S L$} & \multirow{2}{*}{$F R$} & \multirow{2}{*}{ SEM } & \multirow{2}{*}{$\boldsymbol{M}$} & \multicolumn{3}{|c|}{ PS Effect } \\
\hline & & & & & & & $L$ & $Q$ & $C$ \\
\hline 0 & $32.18^{w}$ & $34.61^{x}$ & $20.28^{\mathbf{y}}$ & $29.96^{w}$ & 0.492 & $* * *$ & $* * *$ & $\mathrm{NS}$ & $* *$ \\
\hline 3 & $52.85^{x}$ & $22.14^{w}$ & $18.03^{w}$ & $22.59^{w}$ & 2.017 & $* * *$ & $* *$ & $* * *$ & $* * *$ \\
\hline 6 & $52.16^{x}$ & $30.97^{w y}$ & $26.57^{y}$ & $34.13^{w}$ & 1.646 & $* * *$ & $*$ & $* * *$ & $* * *$ \\
\hline 12 & $83.16^{\mathbf{x}}$ & $75.85^{\mathrm{xw}}$ & $64.86^{w y}$ & $63.86^{\mathbf{y}}$ & 2.501 & $* *$ & $* * *$ & $* * *$ & $* *$ \\
\hline 24 & $92.58^{x}$ & $86.14^{x}$ & $74.55^{w}$ & $63.53^{y}$ & 1.861 & $* * *$ & $* * *$ & $* * *$ & $* * *$ \\
\hline 48 & $91.48^{x}$ & $86.69^{x}$ & $83.39^{x}$ & $74.36^{\mathrm{w}}$ & 1.816 & $* *$ & $* * *$ & $* * *$ & $* * *$ \\
\hline 72 & $93.43^{x}$ & $90.31^{x}$ & $82.71^{w}$ & $78.12^{y}$ & 0.931 & $* * *$ & $*$ & $*$ & $* * *$ \\
\hline c & $0.110^{x}$ & $0.072^{w}$ & $0.072^{w}$ & $0.063^{w}$ & 0.005 & $* *$ & NS & $\mathrm{NS}$ & NS \\
\hline $\mathbf{a}$ & $31.50^{x}$ & $21.13^{w}$ & $11.60^{y}$ & $22.70^{w}$ & 0.772 & $* * *$ & NS & $* * *$ & $* * *$ \\
\hline b & $62.72^{w}$ & $71.45^{x}$ & $74.15^{x}$ & $56.00^{y}$ & 1.339 & $* * *$ & NS & $* *$ & $* *$ \\
\hline EPD $^{1}$ & $84.57^{x}$ & $76.97^{w}$ & $69.53^{y}$ & $64.92^{z}$ & 0.437 & $* * *$ & $* * *$ & $* * *$ & $* * *$ \\
\hline $\mathrm{EPD}^{2}$ & $74.63^{x}$ & $63.20^{w}$ & $55.24^{y}$ & $53.63^{y}$ & 0.553 & $* * *$ & $* * *$ & $* * *$ & $* * *$ \\
\hline EPD $^{3}$ & $67.83^{x}$ & $54.88^{w}$ & $46.61^{y}$ & $47.14^{\mathbf{y}}$ & 0.588 & $* * *$ & $* * *$ & $* * *$ & $* * *$ \\
\hline $\mathbf{B} \mathbf{P}^{1}$ & $15.43^{z}$ & $23.03^{\mathbf{y}}$ & $30.47^{w}$ & $35.08^{x}$ & 0.437 & $* * *$ & $* * *$ & $* * *$ & $* * *$ \\
\hline $\mathbf{B P}^{2}$ & $25.37^{y}$ & $36.80^{w}$ & $44.76^{\mathbf{x}}$ & $46.37^{x}$ & 0.553 & $* * *$ & $* * *$ & $* * *$ & $* * *$ \\
\hline $\mathbf{B P}^{3}$ & $32.17^{\mathbf{y}}$ & $45.12^{w}$ & $53.39^{x}$ & $52.86^{x}$ & 0.588 & $* * *$ & $* * *$ & $* * *$ & $* * *$ \\
\hline
\end{tabular}

IT: Incubation time (h); PS: Phenological stages; PF: Pre-flowering stage; FL: Flowering stage; SL: Seed linkage stage; FR: Fruiting stage; SEM: Standard error of means; M: Main effect; L: Linear effect; Q: Quadratic effect, C: Cubic effect; a: the fraction of readily degradable CP (\%), b: the fraction of degradable CP at a measurable rate $(\%)$; c: degradation rate of $\mathrm{CP}\left(\% \mathrm{~h}^{-1}\right)$; $\mathrm{EPD}^{1}$ : effective degradability of $\mathrm{CP}(\%)$ with a rumen outflow rate of 0.02 ; EPD ${ }^{2}$ effective degradability of $\mathrm{CP}(\%)$ with a rumen outflow rate of 0.05 ; $\mathrm{EPD}^{3}$ : effective degradability of $\mathrm{CP}(\%)$ with a rumen outflow rate of 0.08 ; $\mathrm{BP}^{1}$ : bypass protein $(\%)$ with a rumen outflow rate of $0.02 ; \mathrm{BP}^{2}$ : bypass protein $(\%)$ with a rumen outflow rate of $0.05 ; \mathrm{BP}^{3}$ : bypass protein $(\%)$ with a rumen outflow rate of 0.08 . The values with different letters $(\mathrm{x}, \mathrm{w}, \mathrm{y}, \mathrm{z})$ in the same row are statistically different $(\mathrm{P}<0.05)$; NS: Not Significant; $* \mathrm{P}<0.05 ; * *: \mathrm{P}<0.01 ; * * *: \mathrm{P}<0.001$ 
The rapidly degradable (a) DM and CP fraction of SO leaves are presented in Tables 1 and 2. While the PF stage (22.05\%) had a lower readily degradable DM, the FL stage $(48.35 \%)$ had higher readily degradable DM. On the other hand, the lowest readily degradable CP fraction was observed at the SL stage (11.60\%), while the highest one was the PF stage (31.50\%). As shown in Tables 1 and 2, the effective degradability DM and CP of SO leaves, especially at heavily grazed at PF and FL stages, were moderate to high. To our knowledge, there is no information in the literature about in situ digestibility of SO leaves. However, compared to the in situ studies done with some trees and shrubs in the literature, SO leaves' digestibility, collected during the heavily grazed, for $48 \mathrm{~h}$ was higher than some exotic trees and shrubs Spondias mombin L., Antiaris toxicaria Lesch., Baphia nitida Lodd., Grewia carpinifolia Juss., Griffonia simplicifolia (DC.) Baill., Calliandra calothyrsus Meisn., Acacia brevispica Harms, Acacia tortilis (Forssk.) Hayne, Acacia seyal Delile, Acacia nilotica (L.) Delile, Acacia mellifera (M.Vahl) Benth; was similar to Thespesia populnea (L.) Sol. ex Corrêa, Ficus exasperata Vahl.; was lower than Acacia nubica Benth (Kaitho et al. 1993; Apori et al. 1998; Abdulrazak et al. 2000). The degradability of CP of SO leaves was higher than S. Mombin, B. nitida, G. Carpinifolia, G. Simplicifolea, G. Oppositifolia, Ziziphus mauritiana Lam.; was similar to A. Toxicaria, F. Exasperata; was lower than T. Populnea (Apori et al. 1998; Khan et al. 2009).

The GP, estimated parameters of GP, ME, and OMD of SO leaves collected at different phenological stages are given in Table 3. The GP of SO leaves increased with increasing time of incubation. After $96 \mathrm{~h}$ incubation, the gas produced ranged between 20.68 to $27.53 \mathrm{~mL} / 200 \mathrm{mg}$ DM of the substrate. Significant differences between the SO leaves collected at different phenological stages in terms of GP at all incubation times were observed ( $\mathrm{P}<0.05$ for 48,72 , and $96 \mathrm{~h}$; $\mathrm{P}<0.001$ for $3,6,12$, and $24 \mathrm{~h}$ ). In contrast to incubation time, no significant differences were observed for the estimated GP parameters $(\mathrm{P}>0.05)$.

Table 3- In vitro gas production kinetics, Metabolisable Energy and Organic Matter Digestibility of Styrax officinalis L.

\begin{tabular}{|c|c|c|c|c|c|c|c|c|c|}
\hline \multirow{2}{*}{$I T$} & \multirow{2}{*}{$P F$} & \multirow{2}{*}{$F L$} & \multirow{2}{*}{$S L$} & \multirow{2}{*}{$F R$} & \multirow{2}{*}{ SEM } & \multirow{2}{*}{$M$} & \multicolumn{3}{|c|}{ PS Effect } \\
\hline & & & & & & & $L$ & $Q$ & $C$ \\
\hline 3 & $12.24^{\mathrm{x}}$ & $8.53^{w}$ & $8.52^{w}$ & $9.20^{\mathrm{w}}$ & 0.31 & $* * *$ & $* * *$ & *** & $* * *$ \\
\hline 6 & $16.39^{x}$ & $12.51^{w}$ & $12.19^{w}$ & $12.95^{w}$ & 0.39 & $* * *$ & $* * *$ & $* * *$ & $* * *$ \\
\hline 12 & $19.36^{\mathbf{x}}$ & $15.78^{w}$ & $15.39^{w}$ & $16.65^{w}$ & 0.48 & $* * *$ & $* *$ & $* * *$ & $* * *$ \\
\hline 24 & $21.25^{\mathrm{x}}$ & $18.41^{w}$ & $17.61^{w}$ & $19.08^{\mathrm{xw}}$ & 0.59 & $* * *$ & $*$ & $* *$ & $* *$ \\
\hline 48 & $23.87^{x}$ & $20.49^{x w}$ & $18.12^{\mathbf{w}}$ & $20.78^{x w}$ & 1.21 & $*$ & NS & $*$ & NS \\
\hline 72 & $25.59^{x}$ & $22.32^{\mathrm{xw}}$ & $19.52^{w}$ & $21.45^{\mathrm{xw}}$ & 1.44 & $*$ & NS & NS & NS \\
\hline 96 & $27.53^{x}$ & $23.97^{\mathrm{xw}}$ & $20.68^{w}$ & $22.69^{x w}$ & 1.67 & $*$ & NS & NS & NS \\
\hline$a$ & 1.05 & 1.23 & 0.38 & 1.02 & 0.23 & NS & NS & NS & NS \\
\hline$b$ & 23.55 & 20.82 & 19.34 & 20.86 & 1.31 & NS & NS & NS & NS \\
\hline$a+b$ & 24.60 & 22.05 & 19.71 & 21.88 & 1.47 & NS & NS & NS & NS \\
\hline c & 0.174 & 0.131 & 0.185 & 0.175 & 0.018 & NS & NS & NS & NS \\
\hline Gas & $21.25^{x}$ & $18.41^{\mathbf{y}}$ & $17.61^{\mathbf{y}}$ & $19.08^{x y}$ & 0.59 & $* * *$ & $*$ & $* *$ & $* *$ \\
\hline ME & $6.26^{x}$ & $5.49^{y}$ & $5.30^{y}$ & $5.36^{\mathbf{y}}$ & 0.08 & $* * *$ & $* * *$ & $* * *$ & $* * *$ \\
\hline OMD & $43.46^{x}$ & $37.78^{\mathbf{y}}$ & $36.36^{\mathbf{y}}$ & $36.65^{y}$ & 0.52 & $* * *$ & $* * *$ & $* * *$ & $* * *$ \\
\hline
\end{tabular}

IT: Incubation time (h); PS: Phenological stages; PF: Pre-flowering stage; FL: Flowering stage; SL: Seed linkage stage; FR: Fruiting stage; SEM: Standard error of means; M: Main effect; L: Linear effect; Q: Quadratic effect; C: Cubic effect; a: the gas production from the immediately soluble fraction $(\mathrm{mL})$; $\mathrm{b}$ : the gas production from the insoluble fraction $(\mathrm{mL})$; $\mathrm{c}$ : the gas production rate constant for the insoluble fraction $(\mathrm{b})$; $\mathrm{a}+\mathrm{b}$ : potential gas production (mL); Gas: Gas volume after $24 \mathrm{~h}$ of incubation; ME: Metabolizable Energy (MJ/kg DM); OMD: Organic Matter Digestibility (\% DM). The values with different letters $(\mathrm{x}, \mathrm{y})$ in the same row are statistically different $(\mathrm{P}<0.05)$; NS: Not Significant; $*$ : $\mathrm{P}<0.05 ; * *$ : $\mathrm{P}<0.01 ; * * *$ : $\mathrm{P}<0.001$

At all incubation times, the GP of SO leaves collected at the PF stage were significantly higher than those gathered from the other three stages. The relationship between obtained GP and phenological stages from this study showed a cubic trend extending the grazing period. These results were not in agreement with such studies, which showed a decreasing trend as the plant's period increased (Sileshi et al. 1996; Lee et al. 2000; Kamalak 2006). On the other hand, the GP of SO leaves were relatively lower than other shrubs such as Atriplex amnicola, Atriplex nummularia, Atriplex semibaccata Acacia saligna, Maireana brevifolia, Rhagodia preissii (Norman et al. 2010). The lower GP may be related to the species of rumen fluid taken and the high propionate production levels of SO leaves during fermentation. These statements are in agreement with Van Soest (1994) and Getachew et al. (1998).

Based on the estimated parameters of GP, the readily soluble (a), insoluble (b), and gas production rate (c) were not significantly affected by the phenological stages $(\mathrm{P}>0.05)$. This result may be related to the large variety of chemical composition cell wall stricture of SO leaves. Givens et al. (2000) stated that the feed's chemical composition and cell wall structure are often influenced the degradation parameters. Ndlovu \& Nherera (1997) noted that approximately $25 \%$ of the gas production variation was related to changes in the feed's ADF and NDF content. The findings of this research are in agreement with the results of those researchers. 


\section{Conclusions}

The present study was designed to better understand the importance of SO leaves for goat feeding in shrublands by using in situ and in vitro methods. Although the findings should be interpreted with caution, this study has several strengths. Firstly, the findings clearly indicate that degradability of DM, CP, and ME content of SO leaves were ranged between moderate to high and significantly affected by phenological stages. Secondly, the nutritional composition of SO leaves depicted them as good forage sources for goats until the end of the FL stage. Thirdly, SO has the ability to give new shoots in parts that are broken, cut, or grazed for any reason, allowing the grazing period to extend a little more. On the other hand, there is a limitation need to be noted regarding the grazing or feeding with SO leaves, which lies in the fact that the high CT levels. Further in vivo research is required to better understand voluntary consumption of SO leaves by goats and reduce the limiting effect of high CT levels on feed intake.

\section{Acknowledgments}

This study was funded by Tubitak (The Scientific and Technological Research Council of Turkey), Scientific Research Project \# 2180159.

\section{References}

Abdulrazak S A, Fujihara T, Ondiek J K \& Ørskov E R (2000). Nutritive evaluation of some acacia tree leaves from Kenya. Animal Feed Science and Technology 85(1-2): 89-98. https://doi.org/10.1016/S0377-8401(00)00133-4

Ammar H, Lopez S \& Gonzalez J S (2005). Assessment of the digestibility of some Mediterranean shrubs by in vitro techniques. Animal Feed Science and Technology 119(3-4): 323-331. https://doi.org/10.1016/j.anifeedsci.2004.12.013

AOAC (1990). Official Methods of Analysis. 15 ${ }^{\text {th }}$ Edition. Association of Official Analytical Chemist, Washington DC

Apori S O, Castro F B, Shand W J \& Ørskov E R (1998). Chemical composition, in sacco degradation and in vitro gas production of some Ghanaian browse plants. Animal Feed Science and Technology 76(1-2): 129-137. https://doi.org/10.1016/S0377-8401(98)00205-3

Ataşoğlu C, Canbolat Ö, Şahin S \& Baytekin H (2010). Potential nutritive value of browse foliages from Pinus pinaster, Prunus amygdalus and Ulmus glabra. Journal of Animal Production 5(1): 1-7

Boubaker A, Kayouli C, Boukary A \& Buldgen A (2004). Nutrition and feeding strategies of sheep and goats under harsh climates. In: Ben Salem H, Nefzaoui A \& Morand-Fehr P (Eds). CIHEAM (Options Méditerranéennes: Série A, Séminaires Méditerranéens, No: 59) Zaragoza, Spain pp. 147-151.

Bruno-Soares A M, Matos T J S \& Cadima J (2011). Nutritive value of Cistus salvifolius shrubs for small ruminants. Animal Feed Science and Technology 165(3-4): 167-175. https://doi.org/10.1016/j.anifeedsci.2011.02.021

Dziba L E, Scogings P F, Gordon I J \& Raats J G (2003). Effects of season and breed on browse species intake rates and diet selection by goats in the false thornveld of the Eastern Cape, South Africa. Small Ruminant Research 47(1): 17-30. https://doi.org/10.1016/S09214488(02)00235-3

Ertekin İ, Atış İ, Yılmaz Ş, Can E \& Kızılşimşek M (2019). Comparison of shrub leaves in terms of chemical composition and nutritive value. KSU Journal of Agriculture and Nature 22(5): 781-786. https://doi.org/10.18016/ ksutarimdoga.v22i45606.530946

Getachew G, Blümmel M, Makkar H P S \& Becker K (1998). In vitro gas measuring techniques for assessment of nutritional quality of feeds: a review. Animal Feed Science and Technology 72(3-4): 261-281 https://doi.org/10.1016/S0377-8401(97)00189-2

Givens D I, Owen E, Auford R F E \& Omend H M (2000). Forage evaluation in ruminant nutrition. CABI Publishing, Wallingford, United Kingdom p. 283

Goering H K \& Van Soest P J (1970). Forage fiber analyses: apparatus, reagents, procedures, and some applications (No. 379). Agricultural Research Service, US Department of Agriculture.

González-Pech P G, Ventura-Cordero J, Torres-Fajardo R A, Jaimez-Rodríguez P R, Torres-Acosta J F J \& Sandoval-Castro C A (2021). Comparing the browsing behavior of inexperienced kids versus adult goats on heterogeneous vegetation. Applied Animal Behaviour Science 236: 105240. https://doi.org/10.1016/j.applanim.2021.105240

Jaradat N (2020). Phytochemistry, traditional uses and biological effects of the desert plant Styrax officinalis L. Journal of Arid Environments 182: 104253. https://doi.org/10.1016/j.jaridenv.2020.104253

Kaitho R J, Tamminga S \& Bruchem J (1993). Rumen degradation and in vivo digestibility of dried Calliandra calothyrsus leaves. Animal Feed Science and Technology 43(1-2): 19-30. https://doi.org/10.1016/0377-8401(93)90139-B

Kamalak A (2006). Determination of nutritive value of leaves of a native grown shrub, Glycyrrhiza glabra L. using in vitro and in situ measurements. Small Ruminant Research 64(3): 268-278. https://doi.org/10.1016/j.smallrumres.2005.04.027

Kamalak A, Canbolat O, Ozay O \& Aktas S (2004). Nutritive value of oak (Quercus spp.) leaves. Small Ruminant Research 53(1-2): 161-165. https://doi.org/10.1016/j.smallrumres.2003.09.003

Karabulut A, Canbolat O, Ozkan C O \& Kamalak A (2006). Potential nutritive value of some Mediterranean shrub and tree leaves as emergency food for sheep in winter. Livestock Research for Rural Development 18(6):81

Khan N A, Habib G \& Ullah G (2009). Chemical composition, rumen degradability, protein utilization and lactation response to selected tree leaves as substitute of cottonseed cake in the diet of dairy goats. Animal Feed Science and Technology 154(3-4): 160-168. https://doi.org/10.1016/j.anifeedsci.2009.08.011

Kökten K, Gürsoy O, Tukel T \& Hatipoğlu R (2010). Yield and nutritive value of anti-Taurus Mountain rangeland shrubs in Turkey. Journal of Animal and Veterinary Advances 9(4): 716-720. https://doi.org/10.3923/javaa.2010.716.720

Lee M J, Hwang S Y \& Chiou P W S (2000). Metabolizable energy of roughages in Taiwan. Small Ruminant Research 36(3): 251-259. https://doi.org/10.1016/S0921-4488(99)00124-8

Łyczko J, Pawlak A, Augustyński I, Okińczyc P, Szperlik J, Kulma A, Różański H, Obmińska-Mrukowicz B \& Szumny A (2020). Chemical profiling and cytotoxic activity of 150-year old original sample of Jerusalem Balsam. Food and Chemical Toxicology 138: 111183. https://doi.org/10.1016/j.fct.2020.111183. 
Mahall B E, Thwing L K \& Tyler C M (2010). A quantitative comparison of two extremes in chaparral shrub phenology. Flora-Morphology, Distribution, Functional Ecology of Plants 205(8): 513-526. https://doi.org/10.1016/j.flora.2009.12.011

Menke K H, Raab L, Salewski A, Steingass H, Fritz D \& Schneider W (1979). The estimation of digestibility and metabolizable energy content of ruminant feedstuffs from the gas production when they incubated with rumen liquor in vitro. Journal of Agricultural Science 93(1): 217222. https://doi.org/10.1017/S0021859600086305

Metera E, Sakowski T, Słoniewski K \& Romanowicz B (2010). Grazing as a tool to maintain biodiversity of grassland-a review. Animal Science Papers and Reports 28(4): 315-334

Moujahed N, Mustapha C B \& Kayouli C (2005). Sustainable Grazing, Nutritional utilization and quality of sheep and goat. In: Molina Alcaide E, Ben Salem H, Biale K (Eds). CIHEAM (Options Méditerranéennes: Série A, Séminaires Méditerranéens, No: 67) Zaragoza, Spain pp. 413-417

Mountousis I, Papanikolaou K, Stanogias G, Chatzitheodoridis F \& Roukos C (2008). Seasonal variation of chemical composition and dry matter digestibility of rangelands in NW Greece. Journal of Central European Agriculture 9(3): 547-555

Ndlovu L R \& Nherera F V (1997). Chemical composition and relationship to in vitro gas production of Zimbabwean browsable indigenous tree species. Animal Feed Science and Technology 69(1-3): 121-129. https://doi.org/10.1016/S0377-8401(97)81627-6

Norman H C, Revell D K, Mayberry D K, Rintoul D E, Wilmot M G \& Masters D G (2010). Comparison of in vivo organic matter digestion of native Australian shrubs by sheep to in vitro and in sacco predictions. Small Ruminant Research 91(1): 69-80. https://doi.org/10.1016/j.smallrumres.2009.11.019

Ørskov E R \& McDonald I (1979). The estimation of protein degradability in the rumen from incubation measurements weighted according to rate of passage. Journal of Agricultural Science 92(2): 499-503. https://doi.org/10.1017/S0021859600063048

Parissi Z M, Papachristou T G Nastis A S (2005). Effect of drying method on estimated nutritive value of browse species using an in vitro gas production technique. Animal Feed Science and Technology 123-124(1): 119-128 https://doi.org/10.1016/j.anifeedsci.2005.04.046

Perevolotsky A, Landau S, Kababya D \& Ungar E D (1998). Diet selection in dairy goats grazing woody Mediterranean rangeland. Applied Animal Behaviour Science 57(1-2): 117-131. https://doi.org/10.1016/S0168-1591(97)00120-2

Rogosic J, Pfister J A, Provenza F D \& Grbesa D (2006). Sheep and goat preference for and nutritional value of Mediterranean shrubs. Small Ruminant Research 64(1-2): 169-179. https://doi.org/10.1016/j.smallrumres.2005.04.017

Salem A Z M, Salem M Z M, El-Adawy M M \& Robinson P H (2006). Nutritive evaluations of some browse tree foliages during the dry season: secondary compounds, feed intake and in vivo digestibility in sheep and goats. Animal Feed Science and Technology 127(1-2): 251-267. https://doi.org/10.1016/j.smallrumres.2005.04.017

SAS (2016). JMP Version 13.2. SAS Institute Incorporation, Cary, NC, 1989-2019.

Sileshi Z, Emyr O, Mewa S \& Micheal K T (1996). Prediction of in situ rumen dry matter disappearance of Ethiopian forages from an in vitro gas production technique using a pressure transducer, chemical analyses or in vitro digestibility. Animal Feed Science and Technology 61(1-4): 73-87. https://doi.org/10.1016/0377-8401(96)00948-0

Şimşek N \& Kamalak A (2019). Bazı ağaç yapraklarının anti-metanojenik özelliklerinin in vitro gaz üretim tekniği ile belirlenmesi. Black Sea Journal of Agriculture 2(1): 1-5

Sun B, Ricardo-da-Silva J M \& Spranger I (1998). Critical factors of vanillin assay for catechins and proanthocyanidins. Journal of Agricultural and Food Chemistry 46(10): 4267-4274. https://doi.org/10.1021/jf980366j

Tölü C (2009). Farklı keçi genotiplerinde davranış, sağlık ve performans özellikleri üzerine araştırmalar. PhD thesis, University of Çanakkale Onsekiz Mart, Çanakkale, Turkey. Thesis No:259328 in Council of Higher Education Thesis Center.

Tolunay A, Adiyaman E, Akyol A \& Ince D (2009). Herbage growth and fodder yield characteristics of kermes oak (Quecus coccifera L.) in a vegetation period. Journal of Animal and Veterinary Advances 8(2): 290-294

Van Soest P J, Robertson J B \& Lewis B A (1991). Methods for dietary fiber, neutral detergent fiber, and nonstarch polysaccharides in relation to animal nutrition. Journal of Dairy Science 74(10): 3583-3597. https://doi.org/10.3168/jds.S0022-0302(91)78551-2

Van Soest P J (1994). Nutritional Ecology of Ruminants. $2^{\text {nd }}$ ed. Cornell University Press, Ithaca, New York, USA, p. 476

Yesilyurt M K \& Cesur C (2020). Biodiesel synthesis from Styrax officinalis L. seed oil as a novel and potential non-edible feedstock: A parametric optimization study through the Taguchi technique. Fuel 265: 117025. https://doi.org/10.1016/j.fuel.2020.117025

(C) 2022 by the author(s). Published by Ankara University, Faculty of Agriculture, Ankara, Turkey. This is an Open Access article distributed under the terms and conditions of the Creative Commons Attribution (CC BY) license (http://creativecommons.org/licenses/by/4.0/), which permits unrestricted use, distribution, and reproduction in any medium, provided the original work is properly cited. 